\title{
Preprint
}

Published January $25^{\text {th }} 2019$ in Geology today 35 (1), pp. 20-25

Feature

Mesozoic marine reptiles from Spitsbergen and their ecosystems

Lene L. Delsett ${ }^{1}$, Patrick S. Druckenmiller ${ }^{23}, \emptyset$ yvind Hammer ${ }^{1}$, Krzysztof Hryniewicz $^{4}$, Espen M. Knutsen ${ }^{56}$, Maayke J. Koevoets ${ }^{1}$, Hans A. Nakrem ${ }^{1}$, Aubrey J. Roberts ${ }^{7}$, \& Jørn H. Hurum ${ }^{1}$.

${ }^{1}$ Natural History Museum, University of Oslo, Oslo, Norway

I.I.delsett@nhm.uio.no

${ }^{2}$ University of Alaska Museum, Fairbanks, Alaska, USA

${ }^{3}$ Department of Geosciences, University of Alaska Fairbanks, Alaska, USA

${ }^{4}$ Institute of Paleobiology, Polish Academy of Sciences, Warszawa, Poland

${ }^{5}$ Museum of Tropical Queensland, Townsville, Queensland, Australia

${ }^{6}$ College of Science and Engineering, James Cook University, Townsville QLD, Australia

${ }^{7}$ Natural History Museum, London, UK

In the Mesozoic seas, the apex predators were reptiles. From the arctic archipelago of Svalbard, the Spitsbergen Mesozoic Research Group has excavated numerous well preserved marine reptile skeletons in order to understand the biology of these animals and the environment they lived in. The work of eleven field seasons has made this one of the largest and most productive palaeontological research projects in the high Arctic worldwide. The initial eight seasons focused on one of the richest occurrences of Late 
Jurassic - earliest Cretaceous (ca. 150-139 Mya) marine reptiles in the world, and nearly sixty specimens have been collected together with a diverse assemblage of invertebrates, some of which are associated with methane seeps. The last three seasons were spent investigating events further back in time, as Spitsbergen preserve the remains from some of the first marine reptile radiations in the wake of the most devastating extinction in the history of the Earth, at the Permian-Triassic boundary (ca. 252 Mya).

\section{Fieldwork at the top of the world}

The Svalbard archipelago, where Spitsbergen is the main island, is a special place to people studying Earth's history. Preserving relatively undisturbed layers of sedimentary rocks from nearly all the time periods, the archipelago's Mesozoic marine deposits yield an abundance of fossils, which have been studied for more than 150 years. For eleven field seasons (2004, 2006-2012, 2014-16), researchers, students and volunteers from the Spitsbergen Mesozoic Research Group (SMRG), travelled to collect specimens from several exceptionally rich sites, where even in mid-summer, when the midnight sun is up, the temperature hovers just above freezing. Following years of digging, the team has developed unique techniques for excavating, transporting and preparing fragile skeletons and invertebrates from these rather sterile, frozen hillsides. The international research group published their first scientific results in a special volume of the Norwegian Journal of Geology in 2012, followed by a steady stream of publications in the years since. Collectively, it has contributed significantly to the understanding of marine ecosystems at the Jurassic-Cretaceous boundary and is starting to yield results about the first millions of years after the Permian-Triassic boundary. 


\section{The first eight seasons - A marine reptile graveyard}

The break-up of the supercontinent Pangaea about 175 million years ago caused the tectonic plate containing present day Spitsbergen, then covered by a shallow sea, to drift to an approximate latitude of $63^{\circ}-66^{\circ} \mathrm{N}$ by the Late Jurassic (ca. 150-145 mya). The Boreal seas were connected to the Tethys Sea in the south, by seaways between present day Norway and Greenland (North East Atlantic Seaway), and through Western Russia. Marine reptiles from this time period at Spitsbergen first became known in 1914, when the Swedish palaeontologist Carl Wiman described the isolated remains of a plesiosaur, a long-necked, four-flippered marine reptile. Some years later, in 1931, additional plesiosaur remains were found in the same area by three American physicians who were overwintering in Longyearbyen, the main settlement at Svalbard, to study the epidemology of the common flu. Except from scattered reports of fossil bones found during geological mapping campaigns, no further attention was given to the Jurassic marine reptiles on Spitsbergen. In 2001, students from the University Centre in Svalbard found a well-preserved limb and partial neck of a plesiosaur on the slopes of Janusfjellet Mountain, and contacted the Natural History Museum at the University in Oslo, sparking the first SMRG excavations in 2004.

The locality now known as the Slottsmøya Member Lagerstätte, is a rock unit with an exceptionally high number of ichthyosaurs and plesiosaurs from the latest Jurassic and crossing into the earliest Cretaceous (ca. 150-139 Mya). The sediments containing the nearly sixty marine reptile specimens collected so far, is a 70-metre-thick sequence of black shales named the Slottsmøya Member, of the Agardhfjellet Formation, preserving approximately 12 million years of depositional history. Extensive sedimentological and geochemical studies have confirmed that the seafloor environment experienced long periods of calm conditions, occasionally disturbed by large storms, and was relatively low in oxygen. The invertebrate 
fossil record gives a vivid picture of the marine ecosystem and provides good

biostratigraphical age correlations for the vertebrate remains. The benthic fauna included bivalves, gastropods, bristle worms and foraminifera, indicating that the bottom water was at least partly oxygenated at times. An unexpected byproduct was the discovery of an echinoderm fauna with articulated crinoids, brittle stars, starfish and sea urchins, preserved in a storm deposit. In the water column lived squid-like animals; belemnoids and ammonites, of which the former left behind large numbers of arm hooks in the sediment, some of them more than four centimetres in length. Fish are preserved only as fragments, but are important as they were not previously known from the Jurassic of Spitsbergen. So far 30 new species have been described from the Slottsmøya Member Lagerstätte; four ichthyosaurs, four plesiosaurs, five bivalves, two brachiopods, six gastropods, six foraminiferans, two sea stars and one brittle star.

By combining data from the fossils and rock record, the team has been able to identify and explain preservation and diversity trends through the member. The results show that the articulated marine reptile skeletons, which make up less than 20 percent of the specimens, are mainly found in parts of the section with high levels of total organic carbon, and that bivalves more frequently occur in parts of the unit that contain few reptiles, strengthening the theory that low oxygen levels contributed to their preservation.

Abundant invertebrate fauna has also been discovered in sixteen carbonate bodies, one metre across, found within the black shale terrain while searching for marine reptiles. The carbonate bodies initially puzzled the scientists, but investigations showed that they have been formed at ancient methane seeps, and make up one of only eight Jurassic seep localities with fauna known worldwide. The seeps from the Slottsmøya Member were formed by anaerobic oxidation of biogenic methane released from a shallow source, and the 
formation of carbonate within the sediment, forming a hardground habitat for benthic organisms. The seep fauna is very species rich, with a total of 54 species. Some of these species may have depended on the seep chemistry, either through chemosymbionts or by feeding on bacterial mats. The seeps are mostly comparable to recent seeps on continental shelves, which are populated by diverse opportunist communities. This contrasts the deepwater seeps with mass-accumulation of chemosymbiotic tube worms, bivalves and bacteriafeeding gastropods.

\section{The marine reptiles}

Ichthyosaurs were a large group of marine reptiles with a dolphin-like body, known from the entire globe. In the Jurassic, they evolved a spindle-shaped body with small hind fins and a large tail used for fast, sustained swimming. It was previously believed that ichthyosaurs with this body type were in decline by the Late Jurassic, that few taxa survived across the Jurassic- Cretaceous boundary, and that Cretaceous ichthyosaur diversity was low. This picture has changed the last ten years, mainly because of insights from new fossil localities, of which Slottsmøya Member Lagerstätte is one of the richest. The Late Jurassic-Early Cretaceous is now seen as a heyday for ichthyosaurs, with the evolution of new groups. The Slottsmøya Member Lagerstätte also contributes to the understanding of evolutionary relationships in the complex ichthyosaur family tree, and can potentially explain how the Late Jurassic seas were connected, as interesting similarities have been found between highlatitude taxa in Russia, Spitsbergen, Alaska and South America.

The ichthyosaur specimens recovered from the Slottsmøya Member Lagerstätte exhibit a wide range of sizes. Adult ichthyosaurs varied from between three and four to more than six meters, the latter being relatively large for Late Jurassic ichthyosaurs. The 
most impressive specimen is the type specimen of Cryopterygius kristiansenae, an exceptionally well preserved, nearly complete skeleton of a 5.5-metre-long ichthyosaur. It preserves all body parts except from the very tip of the tail, making it one of the most complete specimens from the Late Jurassic worldwide. An additional three new species have been described from the site: Palvennia hoybergeti, Janusaurus lundi and Keilhauia nui. Some of the other twelve described and fourteen undescribed ichthyosaur specimens from the Slottsmøya Member Lagerstätte hint to an even higher diversity, but are unfortunately too incomplete to be described as new species.

Plesiosaurs are another group of marine reptiles that used two set`s of powerful flippers to 'fly' through the water. Some, like the elasmosaurs, possessed a small head at the end of a ridiculously long neck, whereas others, commonly known as pliosauroids, had short necks but relatively massive skulls. The evolutionary relationship between major plesiosaur groups has been under debate for decades, but is slowly approaching a consensus.

Traditionally, long-necked plesiosaurs were placed in separate groups from the short-necked types; however with recent insights into their evolutionary history, these body plans appear to have evolved independently multiple times. The thirty plesiosaur specimens from the Slottsmøya Member fill a temporal gap between the Middle-Late Jurassic forms of Europe and the Early-Late Cretaceous species in North America. In addition, the Slottsmøya Member specimens expand the geographical range of plesiosaurians from this time period. Two new genera and three species of a family of long-necked plesiosaurs, Cryptoclididae, have so far been described from the Slottsmøya Member, illustrating a high diversity of this family up to the Jurassic-Cretaceous boundary. The new taxa were named Djupedalia engeri, Spitrasaurus wensaasi and Spitrasaurus larseni, after financial sponsors and volunteers of the research group. Spitrasaurus wensaasi holds a record with 60 neck vertebrae, more than 
any other Jurassic plesiosaur known. This has given insights into the potential convergent evolution between the Jurassic long-necked plesiosaurs and the well-known long-necked elasmosaurids from the Cretaceous period, some of which had as many as 76 neck vertebrae. Another nearly complete long-necked plesiosaur from the Slottsmøya Member, currently under description, will hopefully yield further answers about these relationships. Unlike all of the Slottsmøya plesiosaurs excavated so far, this specimen has a complete skull. As the skulls of long-necked plesiosaurs have an unfortunate tendency to drop off during decomposition while the carcass is floating belly-up on the surface, exceptionally few are found. As a result, this specimen is important for understanding changes in the skull anatomy of these animals between the Jurassic and the Cretaceous.

Partial remains of two very large (10-13-metre-long) pliosauroids belonging to the genus Pliosaurus have also been described. Despite being an iconic plesiosaur taxon, Pliosaurus is poorly known, and therefore the Spitsbergen material of a new species, Pliosaurus funkei, is important in understanding the morphology, palaeobiology, and evolutionary history of this group. A selection of the vertebrae and jaw bones from the specimens were thin-sectioned and studied with a microscope. Within the calcite and barite in the bone pore spaces, the team found fluid inclusions containing organic molecules trapped at different temperatures. A few samples of these molecules (lipids) may actually originate from the animal itself. Bones from the limbs of long-necked plesiosaurs were also studied in thin sections. The inner bone structure suggested an active marine animal with rapid growth and high metabolism, potentially with body temperature above the ambient sea temperature.

The last three field seasons - recovery after a mass extinction 
The Permian-Triassic boundary (252 mya) represents the most devastating event in the history of life on Earth. Likely due to extensive volcanism forming the Siberian Traps, followed by rapid climate change and ocean acidification, between 80 and $95 \%$ of all marine species went extinct. At that time, present day Spitsbergen was part of the sea bed in the large embayment of the Panthalassa Ocean on the northern rim of Pangaea, known as the Boreal Ocean, at approximately 42 degrees $\mathrm{N}$. The time immediately following the dramatic Permian-Triassic extinction, represents the start of diversification of many groups that dominated the Earth later in the Mesozoic, among them the secondarily aquatic ichthyosaurs. The earliest known members of this clade were already fully adapted to a marine lifestyle in the Early Triassic, but there is presently no complete fossil record of the transition from land to water. Based on material found elsewhere, we know that early ichthyosaurs had a relatively long tail, and four legs that in many ways resemble those of land-living reptiles. However, many questions remain about the early evolution of this group, including the timing of important evolutionary features such as live birth. The Early Triassic bone beds from Spitsbergen might shed some light of these mysteries. SMRG is working on the recovery after the extinction, and has excavated fossils from some of the first biological radiations, when life was recovering from the cataclysmic events at the Permian-Triassic boundary.

From 2014 and onwards, the group has rediscovered several reptile-bearing localities, originally described and named by researchers in the 1800 s. The first Triassic marine reptiles from Svalbard were described as early ichthyosaurs by the British surgeon and palaeontologist John Whittaker Hulke in 1873 , based on fossils found by the Finnish-Swedish explorer and geologist Adolf Erik Nordenskiöld in 1864 and 1868. Later in the twentieth century, even earlier ichthyosaur relatives were found on Spitsbergen and received 
considerable attention from researchers as they are some of the oldest known worldwide. After the three recent seasons of SMRG excavations, 25,000 skeletal elements and teeth, together with 10,000 coprolites are now being sorted and investigated. The first scientific results of the project describe ammonoids, shark teeth and early ichthyosaurs. The aim is to obtain an understanding of the ecosystem, taphonomy and depositional environment, in a similar manner to what is documented for the Slottsmøya Member Lagerstätte.

\section{Outreach}

Outreach has been a major part of the project from the very beginning, both because it is important to share the scientific results with the public, but also because it helps attract sponsors, facilitating ongoing work at these unique sites. The work of vertebrate palaeontology is time consuming and labour intensive. During the excavations on Spitsbergen, volunteers have helped moving up to 40 tons of shale by hand from each quarry. When back in the lab, it can take months to years to fully prepare, conserve and scientifically describe a new skeleton. For the preparation of the holotype of the ichthyosaur Palvennia hoybergeti, 1000 hours of work were registered. In total, it took eight years from the start of the project until it produced publications, which is a very long time in the current 'publish or perish' regime. At the moment, the group has published 38 peer-reviewed research papers from the Jurassic-Cretaceous part of the project and eight from the Triassic marine ecosystems.

Alternative financial support and a lot of determination have been crucial components for success. This has been made possible through cooperation with the local tourist agency Spitsbergen Travel and the petroleum industry, grants from the National Geographic Society, income from public lectures and personal sponsors. We have so far used 
many outreach strategies, including: a website, blogs on forskning.no and National Geographic (both from excavations and the lab), live video feed from the excavation, social media accounts, popular science talks, two seasons of children science programs in the Norwegian Broadcasting, two TV documentaries in Norwegian Broadcasting, three international TV documentaries (National Geographic, History Channel/BBC, ZDF), activity days for children, appearances in radio, popular science papers, children books, an inflatable, full size pliosaur, press coverage in newspapers and popular science magazines, TV talkshows, podcast, science tourism, ice sculpture, art installation of preparation, fossils as art objects, and even music videos. All this has generated possibilities for funding of this large and logistically challenging project. The scientific results show that the effort was worth all of the hard work, and it is evident that additional results from these projects will continue to emerge in the years to come.

\section{Suggestions for further reading}

Delsett, L.L., Novis L.K., Roberts, A.J., Koeovoets, M.J., Hammer, $\varnothing$. Druckenmiller , P. \& Hurum, J.H. 2016. The Slottsmøya marine reptile Lagerstätte - depositional environments, taphonomy and diagenesis. Geological Society, London, Special Publications, v.434, doi: 10.1144/SP434.2

Hryniewicz, K., Nakrem, H.A., Hammer, Ø., Little, C.T.S., Kaim, A., Sandy, M.R. \& Hurum, J.H. 2015. The palaeoecology of the latest Jurassic-earliest Cretaceous hydrocarbon seep carbonates from Spitsbergen, Svalbard. Lethaia, v.48, pp.353-374.

Hurum, J.H., Nakrem, H.A., Hammer, Ø., Knutsen, E.M., Druckenmiller, P., Hryniewicz, K. \& Novis, L.K. 2012. An Arctic Lagerstätte - the Slottsmøya Member of the Agardhfjellet 
Formation (Upper Jurassic - Lower Cretaceous) of Spitsbergen. Norwegian Journal of Geology, v.92, pp.55-64.

Hurum, J.H., Engelschiøn, V.S., Økland, I., Bratvold, J., Ekeheien, C.P., Roberts, A.J., Delsett, L.L., Hansen, B.B., Mørk, A., Nakrem, H.A., Druckenmiller, P.S. \& Hammer, $\varnothing .2018$. The history of exploration and stratigraphy of the Early to Middle Triassic vertebrate bearing strata of Svalbard (Sassendalen Group, Spitsbergen). Norwegian Journal of Geology, v.98, pp.165-174.

Website with blogs from each field season and frequently asked questions: www.nhm.uio.no/pliosaurus

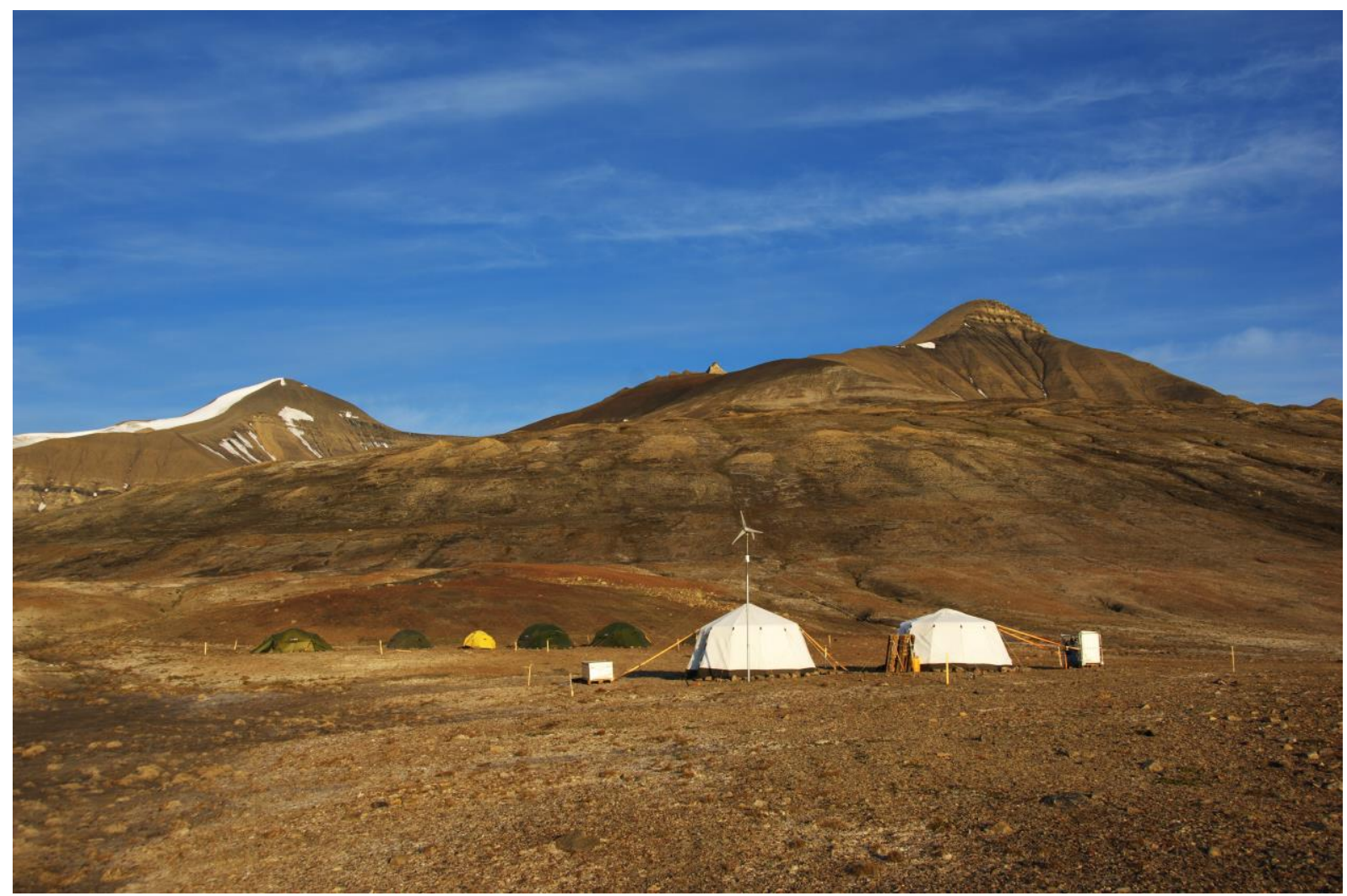



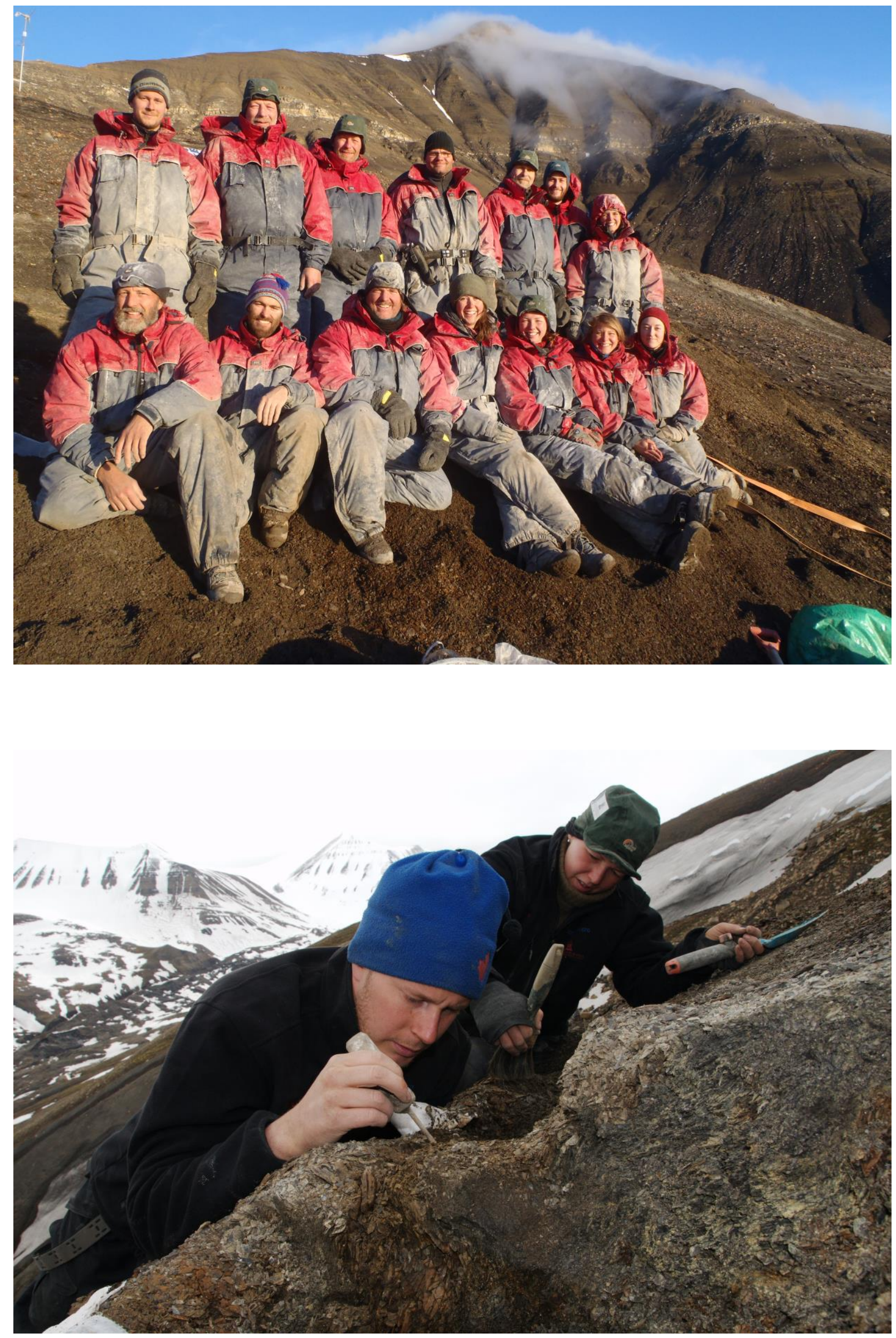

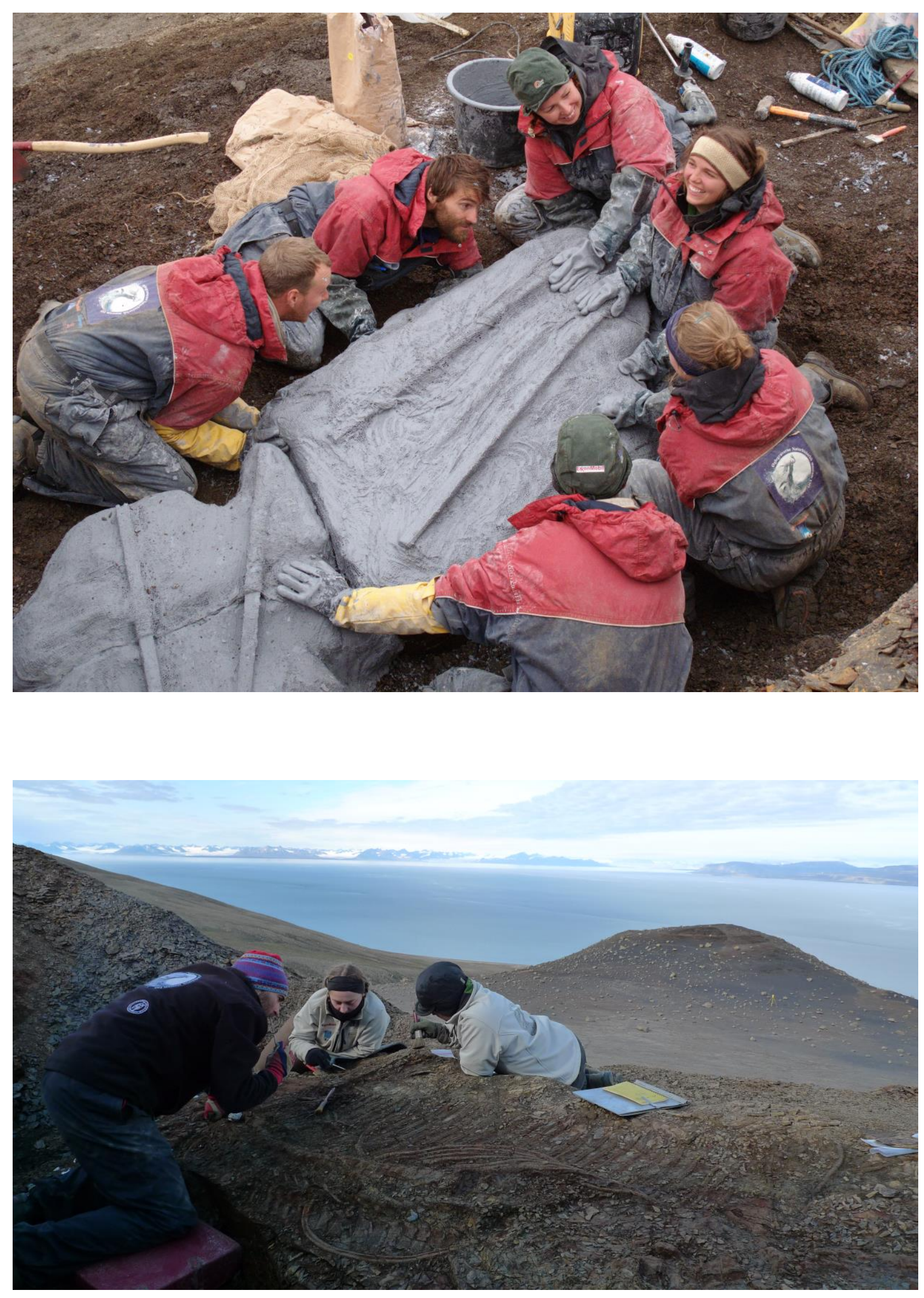

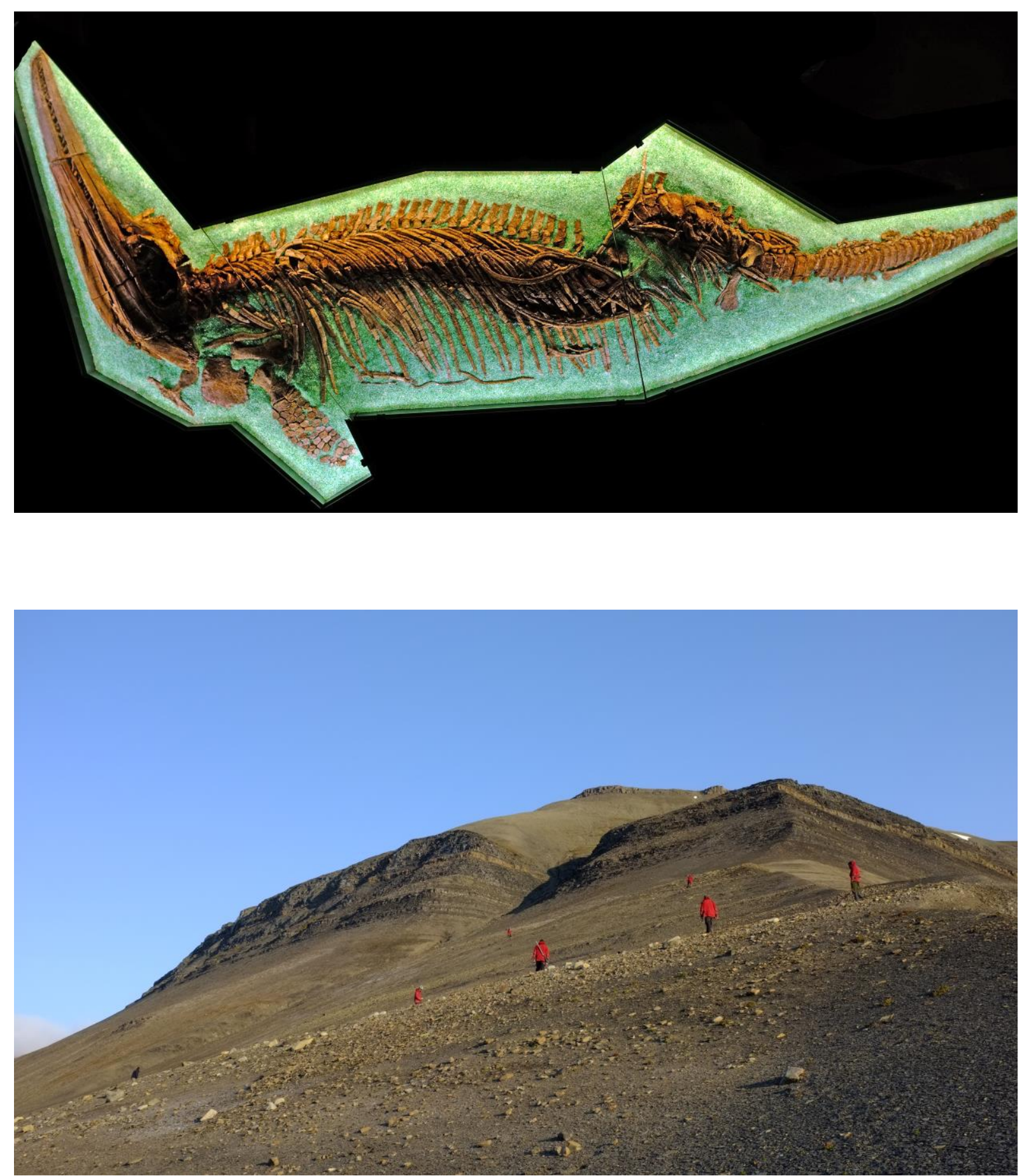

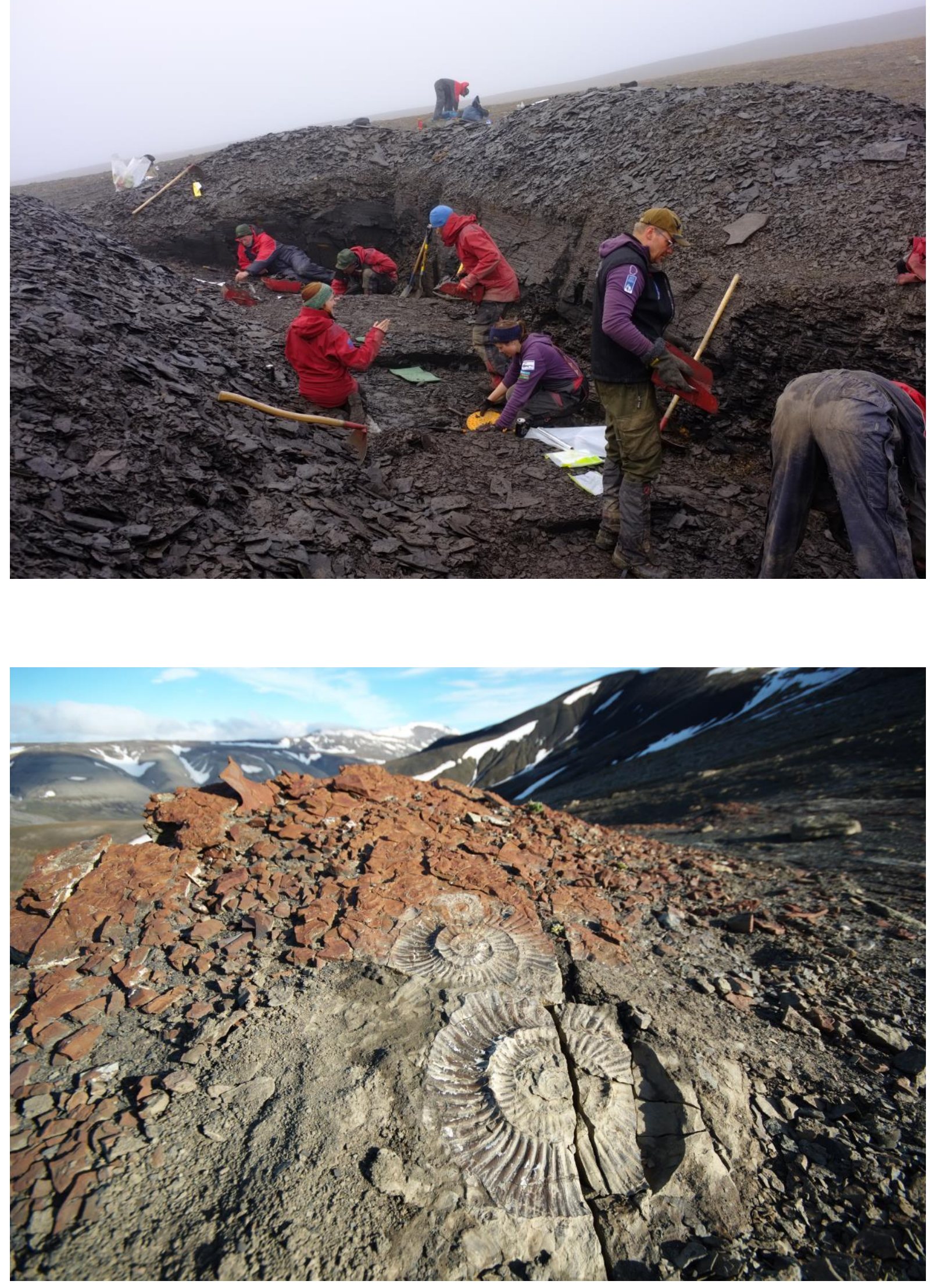